\title{
Age-related Changes in DNA Methylation Status of hTERT Gene Promoter of Oral Epithelial Cells
}

\author{
Stephane Flaviane de Oliveira Bezerra, Ludimila de Araújo Costa, Priscylla Alves \\ Nascimento de Freitas and Naila Francis Paulo de Oliveira* \\ Departamento de Biologia Molecular; Centro de Ciências Exatas e da Natureza; Universidade Federal da Paraíba; \\ João Pessoa - PB - Brasil
}

\begin{abstract}
The purpose of this study was to investigate the effect of aging on the DNA methylation status of two genes involved in tumorigenesis (telomerase gene hTERT and DNA repair gene- MLH1) and one in metabolism (methylenetetrahydrofolate reductase gene- MTHFR) in oral epithelial cells. DNA methylation analysis was performed by Methylation Sensitive Restriction Enzymes (MSRE) of healthy oral epithelial cells of child (6-10 years, $n=21)$, young (20-25 years, $n=19)$ and elderly (over 60 years, $n=25)$. The results for the hTERT gene showed significant variation in the methylation frequency at $C p G$ dinucleotides among the groups $(p=0.0001)$, with the methylated condition more frequently in children and young people. In relation to MLH1 and MTHFR, no differences were observed among the groups and the unmethylated condition were present in most individuals ( $p>0.05)$. Thus, it was concluded that aging of oral epithelial cells was associated with hypomethylation of the hTERT gene promoter and this could be a promising marker for screening a set of age-related alterations.
\end{abstract}

Key words: epigenetic, DNA methylation, aging, DNA repair, telomerase, MTHFR

\section{INTRODUCTION}

Aging is traditionally thought to be caused by numerous complex and interacting factors. These include oxidative DNA damage, depletion of selfrenewing stem cells, mitochondrial and nuclear genome mutations, especially in DNA repairs genes, shortening of telomeres, and other processes (Kirkwood 2005). Human aging has not been fully understood in terms of the genetic setting. Epigenetic profile is an alternative mean of explaining age-associated alterations. In fact, an increasing body of evidence suggests that many manifestations of aging are epigenetic (Koch and Wagner 2011; Huidobro et al. 2013).

Epigenetics is defined as the "study of stable genetic modifications that result in changes in gene expression and function without a corresponding alteration in DNA sequence" (Probst et al. 2009). Epigenetic mechanisms comprise DNA methylation, post-translational histone modifications, and non-coding RNAs, and they are related to gene expression and chromatin structure. Among epigenetic modifications, DNA methylation has been best characterized. $\mathrm{CpG}$ dinucleotides in the mammalian genome can be enzymatically methylated at cytosines by at least three DNA methyltransferases (DNMTs) (DNMT1, DNMT3A and DNMT3B). Dinucleotides CpG "methylable" are not randomly distributed in the human genome; they appear in CpG-poor regions and CpG-rich regions denominated as $\mathrm{CpG}$ islands, which are present in the promoters of many genes. DNA methylation is

*Author for correspondence: naila_francis@yahoo.com.br 
a crucial mechanism in the control of gene activity and nuclear architecture (Portela and Esteller 2010).

Studies have shown that DNA methylation changes during the aging of blood cells (Tra et al. 2002; Fuke et al. 2004; Gowers et al. 2011; Heyn et al. 2012; Madrigano et al. 2012), skin (Raddatz et al. 2013) muscle (Zykovich et al. 2013) and saliva (Bocklandt et al. 2011). Periodontitis and cancer are age-related diseases in which epigenetic mechanisms are involved (Oliveira et al. 2009; Towle et al. 2013).

hTERT codifies catalytic subunit of telomerase, which is involved in replicative life span regulation by maintaining telomere length (Poole et al. 2001). MLH1 (mutL homolog 1) codifies a component of the principal DNA repair pathways that contributes to genomic stability by targeting base-base mismatches and insertion/deletion loops occurring during replication, homologous recombination and DNA damage (Schofield and Hsieh 2003). Methylenetetrahydrofolate reductase (MTHFR), a key enzyme in folate metabolism, is involved in the generation of $\mathrm{S}$ adenosylmethionine (SAM), the universal methyl donor for methylation reactions (Ly et al. 2012). Based on these facts, it was hypothesed that DNA methylation status in two genes involved in tumorigenesis (hTERT and MLHI) and one in metabolism (MTHFR) could be influenced by aging and here the focus was on oral epithelial cells.

\section{MATERIALS AND METHODS}

\section{Subject Population}

Prior to commencement, the study design was approved by the Institutional Review Board of the Federal University of Paraiba (protocol number 149/12). All the volunteers were informed about the nature of the proposed study and written consent was taken from all. A convenience sample of unrelated male and female subjects was recruited for the study. All the subjects were in good general health. The exclusion criteria included the individuals with a history of oral cancer, with clinical signs of damage to the oral mucosa and smokers. It was noted that the mouthwash of some elderly had little bleeding. Sixty-five subjects aged 06-69 years old were enrolled in the study.

\section{Sample Collection}

The subjects were classified into one of three categories based on their age. Of these, 21 were children (mean age: $8.24 \pm 1.50$ years; mean \pm SD; $47.72 \%$ boys and $52.28 \%$ girls), 19 were young (mean age: $21.52 \pm 1.81$ years; $52.63 \%$ men and $47.37 \%$ women) and 25 were elderly (mean age: $64.84 \pm 4.56$ years; $28 \%$ men and $72 \%$ women). Oral epithelial cell samples were collected and the DNA was purified as previously described (de Arruda et al. 2013).

\section{DNA Methylation Analysis}

Methylation analysis was performed by Methylation Sensitive Restriction Enzymes (MSRE). Polymerase chain reaction (PCR) analysis, relying on the inability of restriction enzymes to cut methylated sequences. The sites examined were recognized by one of the following restriction enzymes, whose activity was always blocked by $\mathrm{CpG}$ methylation: HhaI and HpaII.

\section{DNA digestion}

Genomic DNA (50 ng) was completely digested with the restriction enzymes in a total volume of $20 \mu \mathrm{L}$, as recommended by the manufacturer (New Englands Biolabs, Beverly, MA). The reaction of each restriction enzyme was conducted in an individual manner. The concentrations of the restriction enzymes, as well as the amount of DNA to be digested, have been previously described and calculated (Hashimoto et al. 2007).

\section{DNA amplification}

A semi-quantitative PCR technique was performed in order to compare methylation levels in the different groups. Therefore, a specific number of cycles of the PCR reaction was defined at the exponential phase of amplification. hTERT: After digestion, $4.8 \mu \mathrm{L}$ (12 ng) of each solution was pipetted into a 15 $\mu \mathrm{L}$ PCR mixture containing 7.5 $\mu \mathrm{L}$ Go Taq Green Master Mix (Promega Corporations, Madison, WI, USA), $1.0 \mu \mathrm{L}(10 \mathrm{pmol})$ each primer: sense (5'-AGTGTTGCAGGGAGGCACT3) and antisense (5' GCCTAGGCTGTGGGGTAAC-3'), with 267 bp (GenBank accession number AF097365.1). The PCR was performed under the following conditions: $30 \mathrm{x}\left(95^{\circ} \mathrm{C}, 1 \mathrm{~min} ; 59^{\circ} \mathrm{C}, 1 \mathrm{~min}\right.$; $\left.72^{\circ} \mathrm{C}, 1 \mathrm{~min}\right) . M L H 1$ : After digestion, $8 \mu \mathrm{L}(20$ 
ng) of each solution was pipetted into a $15 \mu \mathrm{L}$ PCR mixture containing 7.5 $\mu \mathrm{L}$ Go Taq Green Master Mix (Promega Corporations, Madison, WI, USA), $1.0 \mu \mathrm{L}$ (10 pmol) each primer: sense (5'-CGCTCGTAGTATTCGTGC-3') and antisense (5'-TCAGTGCCTCGTGCTCAC-3'), with 606 bp (Kane et al. 1997). The PCR was performed under the following conditions: $33 \mathrm{x}\left(95^{\circ} \mathrm{C}, 1\right.$ $\left.\min ; 59^{\circ} \mathrm{C}, 1 \mathrm{~min} ; 72^{\circ} \mathrm{C}, 1 \mathrm{~min}\right)$. MTHFR: After digestion, $4.8 \mu \mathrm{L}(12 \mathrm{ng})$ of each solution was pipetted into a $15 \mu \mathrm{L}$ PCR mixture containing $7.5 \mu \mathrm{L}$ Go Taq Green Master Mix (Promega Corporations, Madison, WI, USA), $1.0 \mu \mathrm{L}$ (10 pmol) each primer: sense (5'CGCGTCACATGACGATAAAG-3'), antisense (5'-TTACACTAATCCCGCGAAGG-3'), with 392 bp (GenBank accession number AF257484.1). The PCR was performed under the following conditions: $35 \mathrm{x}\left(95^{\circ} \mathrm{C}, 1 \mathrm{~min} ; 55^{\circ} \mathrm{C}, 1 \mathrm{~min}\right.$; $\left.72^{\circ} \mathrm{C}, 1 \mathrm{~min}\right)$.

\section{Electrophoresis}

Amplified PCR samples $(6.0 \mu \mathrm{L})$ were carried on $6 \%$ polyacrylamide gels and subjected to electrophoresis. DNA bands were detected after Gel Red (Biotium) stain. Amplified DNAs of hTERT, MLH1 and MTHFR genes were used as controls for restriction enzymes. An input of 50 ng of amplified DNA was submitted for the restriction of each enzyme to ensure their effectiveness. The non-enzyme-treated control DNA sample was always amplified with the primers, in parallel with the enzyme-treated samples, and both were subjected to electrophoresis in adjacent lanes. This provided a positive control for the PCR reaction and for DNA loading.

\section{Statistical Analysis}

Differences among groups were compared by $\chi^{2}$ Test at level of $5 \%$.

\section{RESULTS AND DISCUSSION}

In the present study, Methylation Sensitive Restriction Enzymes were used as methodology. Thus, PCR amplification absence indicated the absence of methylation and the presence of bands indicated partial or total DNA methylation. Here, partially methylated samples were considered as methylated. It must also be noted that besides buccal epithelial cells, the salivary rinses could also contain some other cells such as neutrophils and monocytes, especially in the elderly persons who had periodontitis. However, the concern was collecting the cells from the buccal mucosa, which had no clinical signs of inflammation, but the possibility of the presence of changes in gingival tissue in the elderly persons could not be ruled out. In fact, it was observed that the mouthwash of some elderly persons had little bleeding.

There was loss of DNA methylation during the aging of oral cells for hTERT gene promoter but not for MLHI neither MTHFR. The results for each $\mathrm{CpG}$ site (gcgc and $\mathrm{ccgg}$ ) are shown in Figures 1, 2 and 3.

hTERT - The CpG dinucleotides investigated in the $h T E R T$ gene promoter ranging from -697 to 337. These regions respond to transcription factors such as NF-kB and Sp-1 (Cong et al. 1999). In addition, this presented typical $\mathrm{CpG}$ islands near the transcriptional start site. There was one $\mathrm{CpG}$ island located in the promoter of hTERT, as verified by MethPrimer Software. The results showed difference between the conditions, methylated and unmethylated among the groups. Previous study with normal cells also showed DNA hypomethylation with advancing age from the peripheral blood analysis of young and elderly subjects (Silva et al. 2008). Another study with normal tissue (bladder, brain, heart, kidney, muscle, and placenta) showed hypomethylation in the proximal $h T E R T$ promoter (ranging -500 to +300 ). However, in this case, tissue age was not revealed (Guilleret and Benhattar 2004).

In relation to oral cells, one study analyzed the cells obtained from gingival tissues and kept in culture \{fibroblasts (NHOF) and senescent normal oral keratinocytes (NHOK) \}. The assay revealed that the hTERT promoter was hypermethylated in NHOF and was gradually methylated during senescence in NHOK (Shin et al. 2003). In tumoral cells, the hypermethylation condition was more frequent and it was already shown in breast, bladder, colon, kidney (Guilleret and Benhattar, 2004), brain (Castelo-Branco et al. 2013) and in leptomeningeal metastasis (Bougel et al. 2013). Interestingly, some studies have shown an inverse relationship to the well-established model in which the methylation presence generally inhibits gene transcription, that is, hypermethylation is associated with $h T E R T$ gene expression. 
$-697$

cgcggggaagtgttgcagggagg cactccgggaggtcccgcgtgcccgtccagggagcaatg cgtcctcgggttcgtcoccagccgcgtctacgcgctccgtcctccccttcacgtccgg cattcgtggtgcccggagccogacgeccogcgtccggacctggaggcagecctgggtct ccggatcaggccagcggccaaagggtcgccgcacgcacctgttcccagggectccacatc atggeccctccctcgggttaccccacagcctaggccgattcgacctctctccgctggggc cctcgctggcgtccctgcaccetgggagcgcgagcggcgcgcgggcggggaaagcgcggcc-337

C

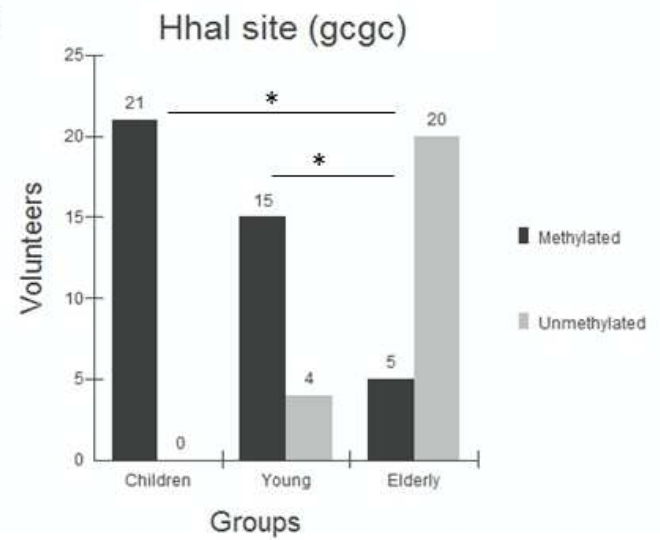

A

\begin{tabular}{|l|l|l|}
\hline Children & Young & Elderly \\
\hline & & \\
\hline
\end{tabular}

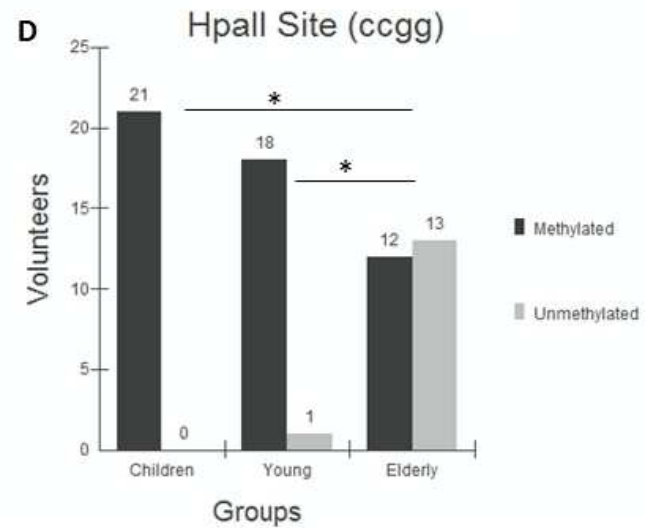

Figure1 - (A) Genomic sequence of the hTERT promoter region ranging from -637 to $-337 \mathrm{bp}$ is presented (GenBank accession number AF097365.1). The $\mathrm{CpG}$ sites studied are underlined. Primers regions are in italic. (B) Bands of representative samples of each group obtained after polymerase chain reaction of hTERT (267 bp); (nd) indicates nondigested DNA samples, followed by digested DNA samples: d1: HhaI; d2: HpaII. (C) Methylation frequency of the HhaI site. (D) Methylation frequency of the HpaII site. $* \mathrm{p}=0.0001 ; \chi^{2}$.

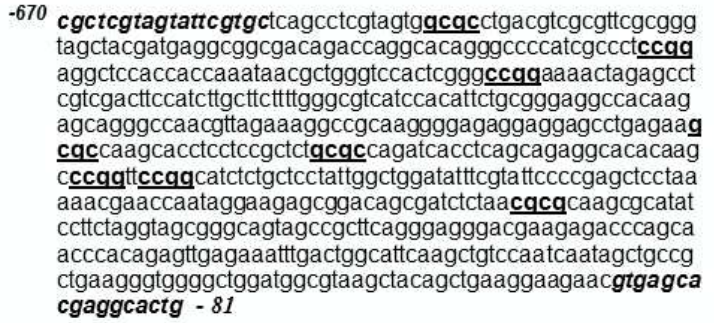

C

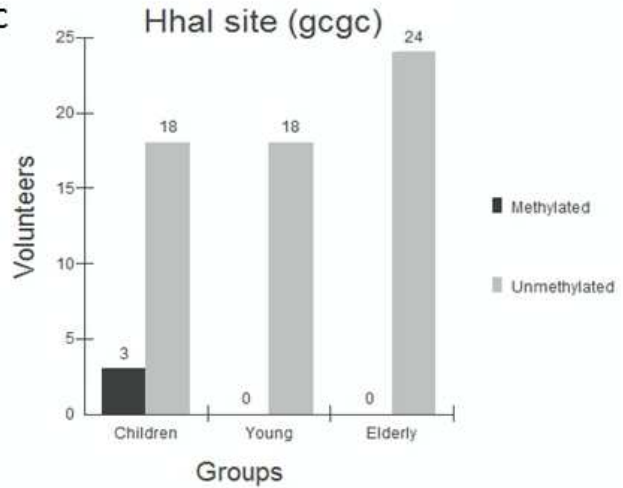

A

\begin{tabular}{|l|l|ll|}
\hline Children & \multicolumn{2}{|c|}{ Young } & Elderly \\
\hline
\end{tabular}

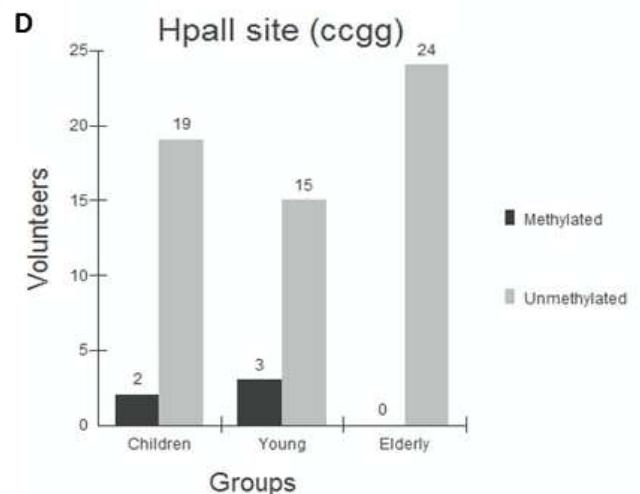

Figure 2 - (A) Genomic sequence of the $M L H 1$ promoter region ranging from -670 to $-81 \mathrm{bp}$ is presented (GenBank accession number U83845.1). The $\mathrm{CpG}$ sites studied are underlined. Primers regions are in italic. (B) Bands of representative samples of each group obtained after polymerase chain reaction of $\mathrm{MLHI}$ (606 bp); (nd) indicates non-digested DNA samples, followed by digested DNA samples: d1: HhaI; d2: HpaII. (C) Methylation frequency of the HhaI site. (D) Methylation frequency of the HpaII site. p>0.05; $\chi^{2}$. 

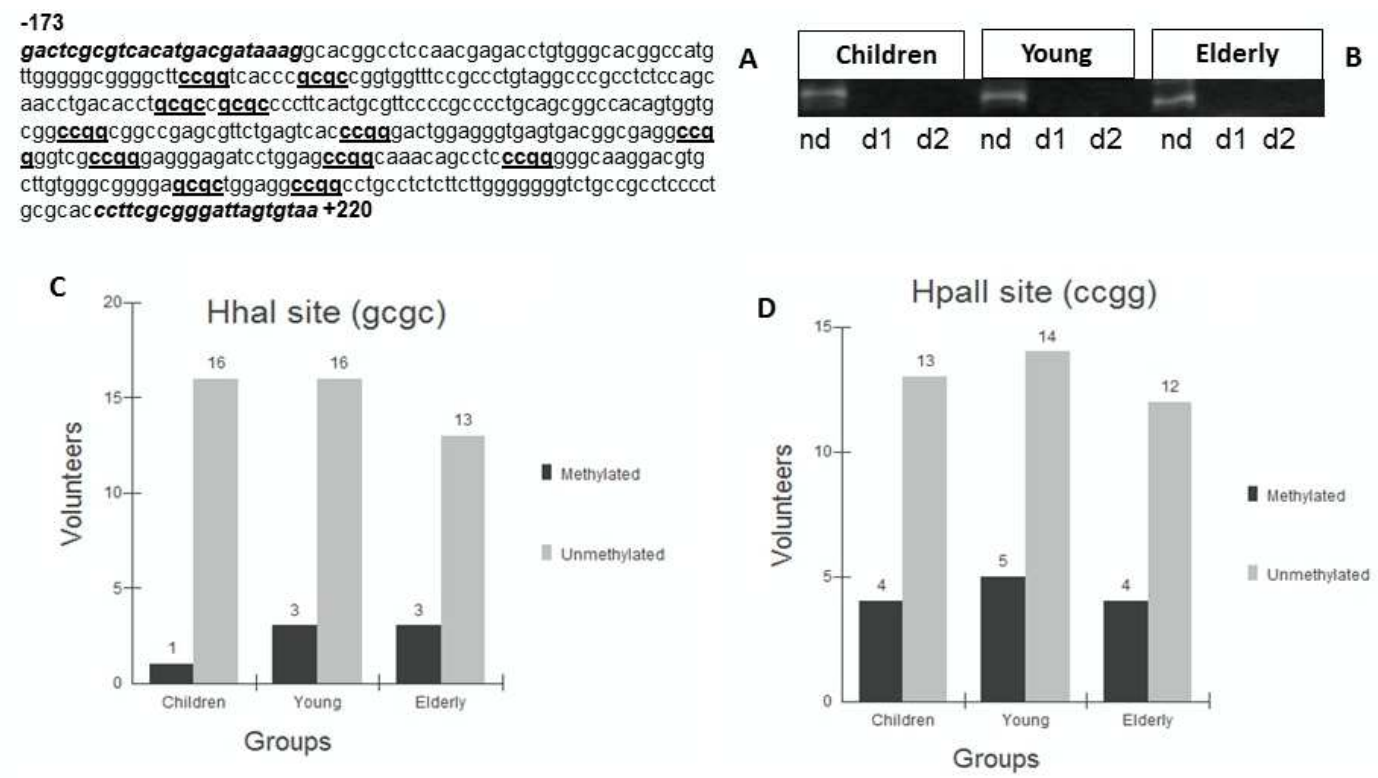

Figure 3 - (A) Genomic sequence of the MTHFR region ranging from -173 to +220 bp is presented (GenBank accession number AF257484.1). The CpG sites studied are underlined. Primers regions are in italic. (B) Bands of representative samples of each group obtained after polymerase chain reaction of MTHFR (392 bp); (nd) indicates non-digested DNA samples, followed by digested DNA samples: d1: HhaI; d2: HpaII. (C) Methylation frequency of the HhaI site. (D) Methylation frequency of the HpaII site. $\mathrm{p}>0.05 ; \chi 2$.

This was observed in tumoral and healthy cells (Devereux et al. 1999; Guilleret et al. 2002; Widschwendter et al. 2004) and suggested that the region of the promoter studied was not the main regulatory sequence and/or possibly another mechanism such as histone modifications could regulate gene expression of $h T E R T$. Iliopoulos et al. (2009) have shown that both mechanisms are involved in the $h T E R T$ regulation. In contrast, some studies with both normal and tumoral cells found a relationship between hypomethylation and gene transcription activation, checked by the treatment with the demethylating agent, 5-Aza-2deoxycytidine (Shin et al. 2003; Iliopoulos et al. 2009). Daniel et al. (2012) suggested that the broad range of mechanisms by which hTERT was regulated in both cancer and normal cells reinforced the need for further studies about hTERT.

$M L H 1$ - The CpG dinucleotide selected for $M L H 1$ gene promoter analysis were located near the region between nucleotides -670 and -81 . These nucleotides were located within two $\mathrm{CpG}$ islands as verified by MethPrimer Software. This region has binding sites for several transcription factors such as AP-1, NF-қВ, ОСТ-1, ОСТ-2, Sp-1, p53 and other (Kane et al. 1997). In this work, eight $\mathrm{CpG}$ sites were studied, four recognized by the enzyme HhaI and four recognized by HpaII enzyme.

The DNA methylation status was similar for all the groups. Recent work with healthy subjects showed that in blood cells, there was loss of methylation in the promoter of the $M L H 1$ gene with advancing age and also the methylation profile was associated with the type of polymorphism in the same gene (Savio et al. 2012). In the present study, no loss of DNA methylation in oral cells was detected. Other studies have found changes in the DNA methylation of $M L H 1$ gene compared with healthy individuals with individuals with cancer, and hypermethylation was detected in colorectal cancer (Kane et al. 1997), gastric cancer (Alves et al. 2011), esophagic cancer (Ling et al. 2011) and lung cancer (Gomes et al. 2014). These studies also found association between hypermethylation and gene repression. In relation to cancer in the oral cavity, the results are controversial. Hypermethylation has been shown in many cases of oral cancer at early stages and in half the cases in the later stages of the disease, suggesting that 
the methylation of $M L H 1$ gene promoter is an early event and is maintained during tumor progression (Czerninski et al. 2009; GonzálezRamirez et al. 2011). In contrast, other authors have shown low rate of $M L H 1$ methylation in oral carcinomas (Ogi et al. 2002; Viswanathan et al. 2003). It has been reported that the differences between results may be a consequence of the different stages of development and progress of the sample studied.

MTHFR- The CpG dinucleotide selected for $M T H F R$ gene promoter analysis were located near the region between nucleotides -320 and +220 . These nucleotides were located within one $\mathrm{CpG}$ island as verified by MethPrimer Software. A total of twelve $\mathrm{CpG}$ sites were sudied, four recognized by the enzyme HhaI and eight recognized by HpaII enzyme. It was observed that the DNA methylation status was similar for all the groups.

The number of studies examining the DNA methylation in the MTHFR has been limited. Most of the studies have been largely restricted to polymorphisms. Recent studies have shown significant correlations between MTHFR hypermethylation and sperm motility and morphology (Botezatu et al. 2014). Some studies have suggested the possible involvement of MTHFR promoter methylation in the pathogenesis of end-stage renal disease patients (Ghattas et al. 2014) and in cervical severity lesions (Botezatu et al. 2013a).

Most of the studies have been performed with blood cells and both hypomethylation and hypermethylation were to be associated with aging of healthy individuals (Tra et al. 2002; Fuke et al. 2004; Gowers et al. 2011; Heyn et al. 2012; Madrigano et al. 2012). In aged skeletal muscle, hypermethylation was found in comparison to samples of younger people (Zykovich et al. 2014). Aged skin revealed no global aberrations, but rather highly localized methylation changes, particularly in promoter and enhancer regions that were associated with altered transcriptional activity (Raddatz et al. 2013). In saliva, DNA methylation of three sites of the EDARADD, TOM1L1 and NPTX2 gene promoters were linear with age over a range of five decades and it was able to predict the age of an individual with an average accuracy of 5.2 years (Bocklandt et al. 2011). In the present study, there was loss of methylation during the aging of oral cells in the promoter of $h T E R T$ and it was detected between young and elderly. However, it lacked between 21 and 60 years old and it was not known when this started to happen exactly.

For both $M L H 1$ and MTHFR, the unmethylated condition was the usual aspect of DNA methylation status for oral epithelial cells and it was not influenced by the aging. However, for some individuals, the methylated condition was noted. It could be associated to others factors that also influenced the DNA methylation status, such as diet, exposition to a variety of compounds (Cortessis et al. 2012) and polymorphisms in DNMTs, MTHFR and MLH1 (McKay et al. 2012; Savio et al. 2012; Inoue-Choi et al. 2013).

The wide range of characteristics (hypomethylation and hypermethylation), typically associated with the aging process could be explained by some studies. Vertino and collaborators (1994) suggested that DNA methyltransferase (DNMT) activity decreased with the age. However, the study was focused on each of the DNMTs present in mammals, the gene expression of DNMT1 and DNMT3a decreased, whereas mRNA amounts of DNMT3B notably increased (Casillas et al. 2003). It has become increasingly frequent that DNA methylation is a promising marker for studying human development, aging and cancer and to tailor interventions based on the epigenetic status. It has already been suggested that access age by DNA methylation status could be useful for forensic science; such a model could estimate the age of a person, based on a biological sample alone (Bocklandt et al. 2011; An et al. 2013). However, as already suggested, it still remains to be studied whether the DNA methylation age of easily accessible fluids/tissues (for example, saliva, buccal cells, blood) could serve as a surrogate marker for inaccessible tissues (for example, brain, kidney and liver) (Horvath 2013), since DNA methylation status is tissue-specific (Slieker et al. 2013).

\section{CONCLUSIONS}

It was concluded that DNA methylation status of $h T E R T$ gene promoter of oral cells could be a promising marker for screening a set of agerelated alterations.

\section{ACKNOWLEDGMENTS}


We thank the volunteers who donated oral mucosa samples. Stephane FO Bezerra and Priscylla AN de Freitas were supported by a fellowship from Conselho Nacional de Desenvolvimento Científico e Tecnológico (CNPq)-Brasil.

\section{REFERENCES}

Alves MK, Ferrasi AC, Lima VP, Ferreira MV, de MouraCampos Pardini MI, Rabenhorst SH. Inactivation of $C O X-2, H M L H 1$ and $C D K N 2 A$ gene by promoter methylation in gastric cancer: relationship with histological subtype, tumor location and Helicobacter pylori genotype. Pathobiology. 2011; 78: 266-276.

An JH, Choi A, Shin KJ, Yang WI, Lee HY. DNA methylation-specific multiplex assays for body fluid identification. Int J Legal Med. 2013; 127: 35-43.

Bocklandt S, Lin W, Sehl ME, Sánchez FJ, Sinsheimer JS, Horvath S, et al. Epigenetic predictor of age. PLoS One. 2011; 6:e14821.

Botezatu A, Socolov D, Iancu IV, Huica I, Plesa A, Ungureanu $\mathrm{C}$, et al. Methylenetetrahydrofolate reductase (MTHFR) polymorphisms and promoter methylation in cervical oncogenic lesions and cancer. $\mathrm{J}$ Cell Mol Med. 2013; 17: 543-549.

Botezatu A, Socolov R, Socolov D, Iancu IV, Anton G. Methylation pattern of methylene tetrahydrofolate reductase and small nuclear ribonucleoprotein polypeptide $\mathrm{N}$ promoters in oligoasthenospermia: a case-control study. Reprod Biomed. 2014; 28:225-231

Bougel S, Lhermitte B, Gallagher G, de Flaugergues JC, Janzer RC, Benhattar J. Methylation of the hTERT promoter: a novel cancer biomarker for leptomeningeal metastasis detection in cerebrospinal fluids. Clin Cancer Res. 2013; 19: 2216-2223.

Casillas MA Jr, Lopatina N, Andrews LG, Tollefsbol TO. Transcriptional control of the DNA methyltransferases is altered in aging and neoplastically-transformed human fibroblasts. Mol Cell Biochem. 2003; 252: 33-43.

Castelo-Branco P, Choufani S, Mack S, Gallagher D, Zhang C, Lipman $\mathrm{T}$ et al. Methylation of the TERT promoter and risk stratification of childhood brain tumours: an integrative genomic and molecular study. Lancet Oncol. 2013; 14: 534-542.

Cong YS, Wen J, Bacchetti S. The human telomerase catalytic subunit $h T E R T$ : organization of the gene and characterization of the promoter. Hum Mol Genet. 1999; 8: $137-142$.

Cortessis VK, Thomas DC, Levine AJ, Breton CV, Mack TM, Siegmund KD, et al. Environmental epigenetics: prospects for studying epigenetic mediation of exposureresponse relationships. Hum Genet. 2012; 131: 15651589.

Czerninski R, Krichevsky S, Ashhab Y, Gazit D, Patel V, Ben-Yehuda D. Promoter hypermethylation of mismatch repair genes, $h M L H 1$ and $h M S H 2$ in oral squamous cell carcinoma. Oral Dis. 2009; 15: 206-213.
Daniel M, Peek GW, Tollefsbol TO. Regulation of the human catalytic subunit of telomerase (hTERT). Gene. 2012; 498: 135-146.

de Arruda IT, Persuhn DC, de Oliveira NF. The MTHFR C677T polymorphism and global DNA methylation in oral epithelial cells. Genet Mol Biol. 2013; 36: 490-493.

Devereux TR, Horikawa I, Anna CH, Annab LA, Afshari CA, Barrett JC. DNA methylation analysis of the promoter region of the human telomerase reverse transcriptase (hTERT) gene. Cancer Res. 1999; 59: 6087-6090.

Fuke C, Shimabukuro M, Petronis A, Sugimoto J, Oda T, Miura K. et al. Age related changes in 5- methylcytosine content in human peripheral leukocytes and placentas: an HPLC-based study. Ann Hum Genet. 2004; 68: 196204.

Ghattas M, El-Shaarawy F, Mesbah N, Abo-Elmatty D. DNA methylation status of the methylenetetrahydrofolate reductase gene promoter in peripheral blood of end-stage renal disease patients. Mol Biol Rep. 2014; 41: 683-688.

Gomes A, Reis-Silva M, Alarcão A, Couceiro P, Sousa V, Carvalho L. Promoter hypermethylation of DNA repair genes $M L H 1$ and $M S H 2$ in adenocarcinomas and squamous cell carcinomas of the lung. Rev Port Pneumol. 2014; 20: 20-30.

González-Ramírez I, Ramírez-Amador V, IrigoyenCamacho ME, Sánchez-Pérez Y, Anaya-Saavedra G, Granados-García et al. $h M L H 1$ promoter methylation is an early event in oral cancer. Oral Oncol. 2011; 47:2226.

Gowers IR, Walters K, Kiss-Toth E, Read RC, Duff GW, Wilson AG. Age-related loss of $\mathrm{CpG}$ methylation in the tumour necrosis factor promoter. Cytokine. 2011; 56: 792-797.

Guilleret I, Benhattar J. Unusual distribution of DNA methylation within the hTERT CpG island in tissues and cell lines. Biochem Biophys Res Commun. 2004; 325: 1037-1043.

Guilleret I, Yan P, Grange F, Braunschweig R, Bosman FT, Benhattar J. Hypermethylation of the human telomerase catalytic subunit ( $h T E R T)$ gene correlates with telomerase activity. Int J Cancer. 2002; 101: 335341.

Hashimoto K, Kokubun S, Itoi E, Roach HI. Improved quantification of DNA methylation using methylationsensitive restriction enzymes and real-time PCR. Epigenetics. 2007; 2: 86-91.

Heyn H, Li N, Ferreira HJ, Moran S, Pisano DG, Gomez A, et al. Distinct DNA methylomes of newborns and centenarians. Proc Natl Acad Sci. 2012; 109: 1052210527.

Horvath S. DNA methylation age of human tissues and cell types. Genome Biol. 2013; 14: R115.

Huidobro C, Fernandez AF, Fraga MF. Aging epigenetics: causes and consequences. Mol Aspects Med. 2013; 34: 765-781.

Iliopoulos D, Satra M, Drakaki A, Poultsides GA, Tsezou A. Epigenetic regulation of hTERT promoter in hepatocellular carcinomas. Int J Oncol. 2009; 34: 391399. 
Inoue-Choi $\mathrm{M}$, Nelson $\mathrm{HH}$, Robien $\mathrm{K}$, Arning $\mathrm{E}$, Bottiglieri T, Koh WP, et al. Plasma Sadenosylmethionine, DNMT polymorphisms, and peripheral blood LINE-1 methylation among healthy Chinese adults in Singapore. BMC Cancer. 2013; 13: 389.

Kane MF, Loda M, Gaida GM, Lipman J, Mishra R, Goldman H, et al. Methylation of the hMLH1 promoter correlates with lack of expression of $h M L H 1$ in sporadic colon tumors and mismatch repair-defective human tumor cell lines. Cancer Res Mar. 1997; 57: 808-811.

Kirkwood TB. Understanding the odd science of aging. Cell. 2005; 120: 437-447.

Koch CM, Wagner W. Epigenetic-aging-signature to determine age in different tissues. Aging (Albany NY). 2001; 3: 1018-1027.

Ling ZQ, Li P, Ge MH, Hu FJ, Fang XH, Dong ZM, et al. Aberrant methylation of different DNA repair genes demonstrates distinct prognostic value for esophageal cancer. Dig Dis Sci. 2011; 56: 2992-3004.

Ly A, Hoyt L, Crowell J, Kim YI. Folate and DNA methylation. Antioxid Redox Signal. 2012; 17: 302-326.

Madrigano J, Baccarelli A, Mittleman MA, Sparrow D, Vokonas PS, Tarantini L, et al. Aging and epigenetics: longitudinal changes in gene-specific DNA methylation. Epigenetics. 2012; 7: 63-70.

McKay JA, Groom A, Potter C, Coneyworth LJ, Ford D, Mathers JC, et al. Genetic and non-genetic influences during pregnancy on infant global and site specific DNA methylation: role for folate gene variants and vitamin B12. PLoS One. 2012; 7: e33290. 1-9.

Ogi K, Toyota M, Ohe-Toyota M, Tanaka N, Noguchi M, Sonoda T, Kohama G, et al. Aberrant methylation of multiple genes and clinicopathological features in oral squamous cell carcinoma. Clin Cancer Res. 2002; 8: 3164-3171.

Oliveira NF, Damm GR, Andia DC, Salmon C, Nociti FH Jr, Line SR, et al. DNA methylation status of the IL8 gene promoter in oral cells of smokers and non-smokers with chronic periodontitis. J Clin Periodontol. 2009; 36: 719-725.

Poole CJ, Andrews GL, Tollefsbol TO. Activity, function, and gene regulation of the catalytic subunit of telomerase (hTERT). Gene. 2001; 69: 1-12.

Portela A, Esteller M. Epigenetic modifications and human disease. Nat Biotechnol. 2010; 28: 1057-1068.

Probst AV, Dunleavy E, Almouzni G. Epigenetic inheritance during the cell cycle. Nat Rev Mol Cell Biol. 2009; 10: 192-206.

Raddatz G, Hagemann S, Aran D, Söhle J, Kulkarni PP, Kaderali L, et al. Aging is associated with highly defined epigenetic changes in the human epidermis. Epigenetics Chromatin. 2013; 6: 36.

Reynolds MA. Modifiable risk factors in periodontitis: at the intersection of aging and disease. Periodontol 2000. 2014; 64: 7-19.
Savio AJ. MLH1 region polymorphisms show a significant association with $\mathrm{CpG}$ island shore methylation in a large cohort of healthy individuals. PLoS One. 2012; 7: e51531.1-9.

Schofield MJ, Hsieh P. DNA mismatch repair: molecular mechanisms and biological function. Annu Rev Microbiol. 2003; 57:579-608.

Shin KH, Kang MK, Dicterow E, Park NH. Hypermethylation of the $h T E R T$ promoter inhibits the expression of telomerase activity in normal oral fibroblasts and senescent normal oral keratinocytes. $\mathrm{Br} \mathrm{J}$ Cancer. 2003; 89: 1473-1478.

Silva PN, Gigek CO, Leal MF, Bertolucci PH, de Labio RW, Payão SL, et al. Promoter Methylation Analysis of SIRT3, SMARCA5, HTERT and CDH1 genes in aging and Alzheimer's Disease. J Alzheimers Dis. 2008; 13: 173-176.

Slieker RC, Bos SD, Goeman JJ, Bovée JV, Talens RP, van der Breggen $R$, et al. Identification and systematic annotation of tissue-specific differentially methylated regions using the Illumina $450 \mathrm{k}$ array. Epigenetics Chromatin. 2013; 6(26):1-12.

Towle R, Truong D, Hogg K, Robinson WP, Poh CF, Garnis C. Global analysis of DNA methylation changes during progression of oral cancer. Oral Oncol. 2013; 49: 1033-1042.

Tra J, Kondo T, Lu Q, Kuick R, Hanash S, Richardson B. Infrequent occurrence of age-dependent changes in $\mathrm{CpG}$ island methylation as detected by restriction landmark genome scanning. Mech Ageing Dev. 2002; 123: 14871503.

Vertino PM, Issa JP, Pereira-Smith OM, Baylin SB. Stabilization of DNA methyltransferase levels and CpG island hypermethylation precede SV40-induced immortalization of human fibroblasts. Cell Growth Differ. 1994; 5: 1395-1402.

Viswanathan M, Tsuchida N, Shanmugam G. Promoter hypermethylation profile of tumor-associated genes $\mathrm{p} 16$, p15, hMLH1, MGMT and E-cadherin in oral squamous cell carcinoma. Int J Cancer. 2003; 105: 41-46.

Widschwendter A, Müller HM, Fiegl H, Ivarsson L, Wiedemair A, Müller-Holzner E, et al. DNA methylation in serum and tumors of cervical cancer patients. Clin Cancer Res. 2004; 10: 565-571.

Zykovich A, Hubbard A, Flynn JM, Tarnopolsky M, Fraga MF, Kerksick C, et al. Genome-wide DNA methylation changes with age in disease free human skeletal muscle. Aging Cell. 2014; 13: 360-366

Received: March 28, 2014; Accepted: June 19, 2014. 